\title{
Formation process of $\mathrm{Si}_{3} \mathrm{~N}_{4}$ particles on surface of $\mathrm{Si}$ ingots grown using silica crucibles with $\mathrm{Si}_{3} \mathrm{~N}_{4}$ coating by noncontact crucible method
}

\author{
Kazuo Nakajima ${ }^{\mathrm{a}, *}$, Kohei Morishita ${ }^{\mathrm{a}}$, Ryota Murai $^{\mathrm{a}}$, Noritaka Usami ${ }^{\mathrm{b}}$
}

a. Graduate School of Energy Science, Kyoto University, Yoshida, Sakyo-ku, Kyoto 606-8501, Japan

b. Graduate School of Engineering, Nagoya University, Furo-cho, Chikusa-ku, Nagoya 464-8603, Japan

\begin{abstract}
A noncontact crucible method was used to investigate the process by which a $\mathrm{Si}_{3} \mathrm{~N}_{4}$ coating material forms $\mathrm{Si}_{3} \mathrm{~N}_{4}$ particles or precipitates on the surface of $\mathrm{Si}$ melts and ingots. Si ingots were grown using crucibles with and without a mixture of $\alpha$ - and $\beta-\mathrm{Si}_{3} \mathrm{~N}_{4}$ particles. The oxygen and nitrogen concentrations in the ingots were measured by Fourier transform infrared spectrometry analysis. The nitrogen concentration in the ingots grown using crucibles with a $\mathrm{Si}_{3} \mathrm{~N}_{4}$ coating was significantly higher than that in ingots grown using crucibles without a $\mathrm{Si}_{3} \mathrm{~N}_{4}$ coating because the nitrogen from the $\mathrm{Si}_{3} \mathrm{~N}_{4}$ coating material dissolved into the Si melt. From orientation image maps analyzed using electron backscattering diffraction patterns of $\mathrm{Si}_{\mathrm{x}} \mathrm{N}_{\mathrm{y}}$ particles on the surface of the ingots, it was clarified that most of the $\mathrm{Si}_{\mathrm{x}} \mathrm{N}_{\mathrm{y}}$ particles were $\beta-\mathrm{Si}_{3} \mathrm{~N}_{4}$. This was also confirmed by X-ray diffraction measurements. The $\mathrm{Si}_{3} \mathrm{~N}_{4}$ particles on the surface of the ingots had several morphologies such as needle-like, columnar, leaf-like, and hexagonal structures. There were two cases in which floating $\mathrm{Si}_{3} \mathrm{~N}_{4}$ particles were formed on the surface of the $\mathrm{Si}$ melts, i.e., the removal and dissolution of the $\mathrm{Si}_{3} \mathrm{~N}_{4}$ coating material. The removed or dissolved $\mathrm{Si}_{3} \mathrm{~N}_{4}$ coating materials, which consisted of a mixture of $\alpha$ - and $\beta-\mathrm{Si}_{3} \mathrm{~N}_{4}$ particles, are considered to have finally changed into $\beta-\mathrm{Si}_{3} \mathrm{~N}_{4}$ in the form of transformers or precipitates on the surface of the Si melt, and these $\beta-\mathrm{Si}_{3} \mathrm{~N}_{4}$ particles became attached to the surface of the ingots.
\end{abstract}

Keywords: A1. Crystal structure; A1. Defects; A2. Growth from melt; A2. Natural crystal growth; A2. Seed growth; B1. Nitrides; B2. Semiconducting silicon; B3. Solar cells

PACS codes: $\quad$ 61.72.Mm, 61.72.uf, 61.72.Ff, 81.05.Cy, 81.10.Fq, 81.40.Lm, 85.60.-q

* Corresponding author. Tel.: +81 757539107

E-mail address: nakasisc@energy.kyoto-u.ac.jp (K. Nakajima) 


\section{Introduction}

To prevent cracking during the casting growth of Si ingots used in solar cells owing to the reaction between the crucible wall and the Si melt, the inner wall of silica crucibles is generally coated with $\mathrm{Si}_{3} \mathrm{~N}_{4}$ materials. However, impurities such as $\mathrm{Fe}$ diffuse from the $\mathrm{Si}_{3} \mathrm{~N}_{4}$ coating materials to the grown ingots, and the quality at the periphery of the ingots is reduced [1-3]. Some $\mathrm{Si}_{3} \mathrm{~N}_{4}$ particles detach from the $\mathrm{Si}_{3} \mathrm{~N}_{4}$ coating material and float on the surface of the Si melt before ingot growth occurs. Such floating $\mathrm{Si}_{3} \mathrm{~N}_{4}$ particles usually appear at the top of the grown ingots. These particles do not strongly affect to the casting growth because the crystal growth starts from the bottom of the crucible, and the floating $\mathrm{Si}_{3} \mathrm{~N}_{4}$ particles do not significantly influence the structure of the ingots. On the other hand, during casting growth using silica crucibles, Si expansion caused by the solidification of the Si melt cannot be effectively controlled because the silica crucibles have insufficient flexibility for stress reduction. We previously proposed the use of a noncontact crucible method to reduce the stress and solid-phase diffusion of impurities in Si bulk crystals [4-6]. We used this method to directly observe floating $\mathrm{Si}_{3} \mathrm{~N}_{4}$ particles on the surface of a $\mathrm{Si}$ melt and to determine the origin of these particles. We were able to confirm the appearance of $\mathrm{Si}_{3} \mathrm{~N}_{4}$ precipitates in a moment because this method had a low-temperature region in the upper central part of the $\mathrm{Si}$ melt, and the initial $\mathrm{Si}_{3} \mathrm{~N}_{4}$ precipitates clearly appeared at the center of the melt surface. We also observed that the crystal structure was strongly affected by the floating $\mathrm{Si}_{3} \mathrm{~N}_{4}$ particles in this method because the $\mathrm{Si}_{3} \mathrm{~N}_{4}$ particles act as nucleation sites for crystal growth and many grains are formed from the particles [4-6].

There are two cases in which floating $\mathrm{Si}_{3} \mathrm{~N}_{4}$ particles are formed on the surface of a $\mathrm{Si}$ melt. In the first case (case I), $\mathrm{Si}_{3} \mathrm{~N}_{4}$ particles float from their removal from the $\mathrm{Si}_{3} \mathrm{~N}_{4}$ coating material on the crucible wall, and the removed $\mathrm{Si}_{3} \mathrm{~N}_{4}$ particles are transformed into other floating $\mathrm{Si}_{3} \mathrm{~N}_{4}$ particles [4-6]. In the second case (case II), $\mathrm{Si}_{3} \mathrm{~N}_{4}$ particles float by precipitating from the nitrogen-saturated $\mathrm{Si}$ melt during cooling when nitrogen is dissolved into the $\mathrm{Si}$ melt from the surface of the $\mathrm{Si}_{3} \mathrm{~N}_{4}$ coating material [7-9]. In this case, the number of floating $\mathrm{Si}_{3} \mathrm{~N}_{4}$ particles is limited by the saturated concentration of nitrogen. In both cases I and II, the floating $\mathrm{Si}_{3} \mathrm{~N}_{4}$ particles become attached to the ingots as small particles during crystal growth, and some of them act as nucleation sites. A large number of small particles appearing on top of the ingots in case I should be in both case I and II. However, it is not clear in case I whether the small particles are $\alpha-\mathrm{Si}_{3} \mathrm{~N}_{4}$ or $\beta-\mathrm{Si}_{3} \mathrm{~N}_{4}$.

The formation of $\alpha-\mathrm{Si}_{3} \mathrm{~N}_{4}$ and $\beta-\mathrm{Si}_{3} \mathrm{~N}_{4}$ particles has been reported in the reaction between nitrogen gas and silicon $[10,11]$. Both $\alpha$ - and $\beta-\mathrm{Si}_{3} \mathrm{~N}_{4}$ have a 
hexagonal structure $[12,13]$, but the lattice constant of $\alpha-\mathrm{Si}_{3} \mathrm{~N}_{4}(\mathrm{c}=5.617 \AA)$ is longer than that of $\beta-\mathrm{Si}_{3} \mathrm{~N}_{4}(\mathrm{c}=2.911 \AA)[12,13]$. It was reported that the $\alpha-\mathrm{Si}_{3} \mathrm{~N}_{4}$ structure $(\mathrm{c}=5.6193 \AA)$ has trigonal symmetry and that the $\beta-\mathrm{Si}_{3} \mathrm{~N}_{4}$ structure $(\mathrm{c}=2.9061 \AA)$ has hexagonal symmetry $[14,15]$. Regarding the morphology, $\alpha-\mathrm{Si}_{3} \mathrm{~N}_{4}$ particles have a trigonal shape with several morphologies including whiskers, elongated particles, and equiaxed particles, and $\beta-\mathrm{Si}_{3} \mathrm{~N}_{4}$ particles have a hexagonal shape [16]. $\quad \alpha-\mathrm{Si}_{3} \mathrm{~N}_{4} \quad$ in powder form has been observed to transform into $\beta-\mathrm{Si}_{3} \mathrm{~N}_{4}$ at temperatures of approximately $1300{ }^{\circ} \mathrm{C}[17,18]$.

Nitrogen dissolves from the surface of the $\mathrm{Si}_{3} \mathrm{~N}_{4}$ coating material into the $\mathrm{Si}$ melt while the Si feedstock is melted and the Si melt is maintained at a high temperature, and it precipitates from the $\mathrm{Si}$ melt as other $\mathrm{Si}_{3} \mathrm{~N}_{4}$ particles during the cooling of the Si melt [19]. Such precipitated $\mathrm{Si}_{3} \mathrm{~N}_{4}$ particles may float on the surface of the Si melt and act as nucleation sites during growth. Søiland et al. reported the growth of Si ingots using silica crucibles coated with a mixture of $\alpha$ - and $\beta-\mathrm{Si}_{3} \mathrm{~N}_{4}$ particles, where the inclusions in the grown ingots were $\beta-\mathrm{Si}_{3} \mathrm{~N}_{4}$ with a hexagonal shape [19]. In their growth, $\beta-\mathrm{Si}_{3} \mathrm{~N}_{4}$ may be formed through a reaction between oxygen or oxides and a nitrogen-saturated $\mathrm{Si}$ melt because $\beta-\mathrm{Si}_{3} \mathrm{~N}_{4}$ particles are more easily formed through the first reaction between oxygen and silicon, and the second reaction between silicon oxide and nitrogen [10]. Alphei et al. reported that amorphous $\mathrm{Si}_{3} \mathrm{~N}_{4}$ floating on the surface of a $\mathrm{Si}$ melt is transformed into $\beta-\mathrm{Si}_{3} \mathrm{~N}_{4}$ crystalline rods with a hexagonal shape [20]. The wetting behavior depended on the $\mathrm{Si}_{3} \mathrm{~N}_{4}$ coating was reported by several researchers $[21,22]$. The effects of the precipitated $\mathrm{Si}_{3} \mathrm{~N}_{4}$ particles are quite serious in both the casting method and the noncontact crucible method because such $\mathrm{Si}_{3} \mathrm{~N}_{4}$ particles generate small-angle grain boundaries and dislocations in the ingots in the casting method $[23,24]$ and act as nucleation sites of grains in the noncontact crucible method [4-6].

In this work, a noncontact crucible method was used to investigate the process by which the $\mathrm{Si}_{3} \mathrm{~N}_{4}$ coating material forms $\mathrm{Si}_{3} \mathrm{~N}_{4}$ particles on the surface of Si melts and ingots for both cases I and II because the floating $\mathrm{Si}_{3} \mathrm{~N}_{4}$ particles clearly affect the structure of the ingots and because the solid-phase diffusion of impurities from the coating material into the ingots is effectively prevented. Several Si ingots were prepared using crucibles coated with a mixture of $\alpha-$ and $\beta-\mathrm{Si}_{3} \mathrm{~N}_{4}$ particles. Small particles on the surface of the ingots were analyzed, and the oxygen and nitrogen concentrations in the ingots were measured. It was determined whether the small particles appearing on the surface of the ingots were $\alpha-\mathrm{Si}_{3} \mathrm{~N}_{4}$ or $\beta-\mathrm{Si}_{3} \mathrm{~N}_{4}$. The process by which the $\mathrm{Si}_{3} \mathrm{~N}_{4}$ coating material forms $\mathrm{Si}_{3} \mathrm{~N}_{4}$ transformers or precipitates 
was also considered. Finally, the effects of the $\mathrm{Si}_{3} \mathrm{~N}_{4}$ particles on the crystal structure were studied.

\section{Experiments}

In the noncontact crucible method used, the Si melt had a low-temperature region in its upper central part to allow Si crystal growth inside. The low-temperature region was formed in the Si melt by controlling the temperature distribution in the designed furnace. Nucleation occurred on the surface of the Si melt from a seed crystal, and a crystal grew inside the melt without touching the crucible wall. The growing crystal was then slowly pulled upward such that the crystal growth was restricted in the low-temperature region. The bottom of the ingots was convex in the growth direction $[5,6]$.

Using this method, Si ingots were grown utilizing silica crucibles 17 or $33 \mathrm{~cm}$ in diameter. The inner wall of the crucible used for the growth of the $\mathrm{Si}$ ingots was coated with a mixture of $9798 \% \alpha-\mathrm{Si}_{3} \mathrm{~N}_{4}$ particles and $23 \% \beta-\mathrm{Si}_{3} \mathrm{~N}_{4}$ particles to prevent the reaction between the Si melt and the crucible ingots during crystal growth. High-purity Si feedstock (more than $9 \mathrm{~N}$ ) was placed together with B-doped p-type or P-doped n-type Si feedstock in the crucible. The amount of Si feedstock used for the growth of the Si ingots was $1.60,6.02$, or $8.08 \mathrm{~kg}$. The feedstock was completely melted by heating in the furnace to temperatures above $1450{ }^{\circ} \mathrm{C}$ in an argon atmosphere. The argon pressure was set to slightly above $0.1 \mathrm{MPa}$ in the present study. The thickness of the Si melt was between 3.0 and $4.0 \mathrm{~cm}$. After heating, a Si seed crystal was dipped into the Si melt, and a necking technique was used for seed growth [25]. The melt was then cooled to control the initial size of the ingot in the low-temperature region. The seed crystal was a Si single crystal obtained from ingots grown using the Czochralski (CZ) method [26]. The orientation and diameter of the seed crystal were (100) and $1.2 \mathrm{~cm}$, respectively. The temperature reduction required to obtain ingots of an appropriate size was between 5 and $45^{\circ} \mathrm{C}$. The temperature reduction is defined as the difference between the starting temperature, at which the initial crystal was first observed to start growing from the seed crystal and the final temperature. The starting temperature was determined by directly observing the melt surface near the seed. The actual temperature reduction was read from a monitor on the heater system. The temperature reduction corresponds to the supercooling for the Si crystal growth. The cooling rate was $0.2{ }^{\circ} \mathrm{C} / \mathrm{min}$. The crystals were then allowed to continue growing while they were slowly pulled upward at a constant rate of about 0.2 or $0.3 \mathrm{~mm} / \mathrm{min}$ without the use of a load cell. Each crystal was continuously rotated at a rate of 1.5 
rpm, and the crucible was continuously rotated at a rate of $1.0 \mathrm{rpm}$ during the ingot growth.

Small particles observed on the surface of the ingots were analyzed by scanning electron microscopy (SEM) and energy-dispersive X-ray spectroscopy (EDX). The orientation and structure of the small particles were analyzed on the basis of their electron backscattering diffraction (EBSD) pattern. The phase of the small particles was identified by X-ray diffraction (XRD) using $\mathrm{Cu}-\mathrm{K} \alpha$ radiation. The oxygen, nitrogen, and carbon concentrations of the ingots were measured from longitudinal and horizontal cross sections of the ingots through Fourier transform infrared spectrometry (FTIR) analysis. The minority carrier lifetime was measured by the microwave photoconductive decay (PCD) method. Passivation was not carried out on the as-cut surface of the ingots before the micro-PCD measurement of the cross section. On the other hand, the sample surface of the wafers was mechanically polished and chemically etched with $\mathrm{HF}$ and $\mathrm{HNO}_{3}$ solution. Then, the sample surface was electrically passivated with quinhydrone and ethanol solution [27] before the measurement of the wafers.

\section{Results}

\subsection{Growth of Si multicrystals from Si melt with floating $\mathrm{Si}_{3} \mathrm{~N}_{4}$ particles on the surface}

p-Type ingots were prepared using crucibles coated with a mixture of $\alpha$ - and $\beta$ $-\mathrm{Si}_{3} \mathrm{~N}_{4}$ particles using the noncontact crucible method [4-6]. In both cases I and II, floating $\mathrm{Si}_{3} \mathrm{~N}_{4}$ particles were formed on the surface of the Si melt. The removal of $\mathrm{Si}_{3} \mathrm{~N}_{4}$ particles from the $\mathrm{Si}_{3} \mathrm{~N}_{4}$ coating layer was the key point for both cases. For case I, Figs. 1 (a) and (b) show a p-type ingot with a diameter of $23 \mathrm{~cm}$ and small particles on its top surface, respectively. The temperature reduction used for the growth was $30{ }^{\circ} \mathrm{C}$. Before the growth of the ingot, a large number of $\mathrm{Si}_{3} \mathrm{~N}_{4}$ particles that detached from the $\mathrm{Si}_{3} \mathrm{~N}_{4}$ coating material were floating on the surface of the Si melt, and some of them acted as nucleation sites during crystal growth. The ingot had many small grains distributed radially from the small particles attached to the seed crystal and other grains distributed from a large island of small particles on the top surface, as shown by the blue and red arrows in Figs. 1 (a) and (b), respectively. Fig. 1 (c) shows an EDX spectrum and the composition of the same small particles on the top surface of the ingot, in which $\mathrm{Si}$ and $\mathrm{N}$ elements were detected together along with $\mathrm{C}$ elements. These results indicate that the small particles were $\mathrm{Si}_{\mathrm{x}} \mathrm{N}_{\mathrm{y}}$. The origin of the carbon was considered to be the coating materials and the graphite material in the chamber of the 
furnace. Fig. 1 (d) shows the distribution of the minority carrier lifetime in an as-cut cross section cut $0.9 \mathrm{~cm}$ below the top surface. The minority carrier lifetime had a radial distribution centered at the seed crystal because the grain boundaries were radially distributed from the $\mathrm{Si}_{\mathrm{x}} \mathrm{N}_{\mathrm{y}}$ particles attached to the seed crystal. The minority carrier lifetime was not too bad below the island of $\mathrm{Si}_{\mathrm{x}} \mathrm{N}_{\mathrm{y}}$ particles on the top surface, as shown by the red arrow. The average minority carrier lifetime in the entire cross section was $6 \mu$ s for the as-cut surface and $31 \mu \mathrm{s}$ for the passivated surface of the wafer. Fig. 2 shows the distribution of Si, C, N, and O elements through a combined EDX image of the small particles, as indicated by the yellow arrow, on the top surface of the same ingot. This image shows that the small particles were $\mathrm{Si}_{\mathrm{x}} \mathrm{N}_{\mathrm{y}}$ with some $\mathrm{SiC}$. The $\mathrm{Si}_{\mathrm{x}} \mathrm{N}_{\mathrm{y}}$ particles had several morphologies, such as needle-like, columnar, and leaf-like structures, which could be observed through a 330x magnification. For case II, Figs. 3 (a) and (b) show a p-type ingot with a diameter of $23 \mathrm{~cm}$ and small particles on its top surface, respectively. The temperature reduction used for the growth was $20{ }^{\circ} \mathrm{C}$. Before the growth of the ingot, small particles originating from the $\mathrm{Si}_{3} \mathrm{~N}_{4}$ coating material were floating on the surface of the Si melt. The ingot had many small grains distributed radially from the small particles on the top surface. Fig. 3 (c) shows an SEM image of the same small particles on the top surface of the ingot, which could be observed at 5000x magnification. Some particles had a hexagonal shape. Fig. 3 (d) shows an EDX spectrum and the composition of the small particles on the top surface of the ingot, in which $\mathrm{Si}$ and $\mathrm{N}$ elements were detected together with $\mathrm{C}$ elements. These results indicate that the small particles on the top surface of the ingot were $\mathrm{Si}_{\mathrm{x}} \mathrm{N}_{\mathrm{y}}$.

\subsection{Nitrogen concentration in ingots and precipitation from Si melt saturated by nitrogen}

Using the noncontact crucible method, several ingots were prepared using crucibles without and with a $\mathrm{Si}_{3} \mathrm{~N}_{4}$ coating with a mixture of $\alpha$ - and $\beta-\mathrm{Si}_{3} \mathrm{~N}_{4}$ particles. To confirm that the nitrogen dissolves from the $\mathrm{Si}_{3} \mathrm{~N}_{4}$ coating material into the $\mathrm{Si}$ melt, the oxygen and nitrogen concentrations in the ingots were measured by FTIR, using crucibles without and with a $\mathrm{Si}_{3} \mathrm{~N}_{4}$ coating. Figs. 4 (a) and (b) show the oxygen and nitrogen concentrations in six ingots, respectively. For each ingot, oxygen and nitrogen concentrations were measured at the center and periphery areas of the ingot. The former and latter concentrations for the same ingot were obtained at the center and periphery areas, respectively. As shown in Figs. 4 (c) and (d), the ingots were grown using two types of crucible, i.e., a-type and b-type, which correspond to crucibles without and with a $\mathrm{Si}_{3} \mathrm{~N}_{4}$ coating, respectively. As shown in Figs. 4 (a) and (b), ingots 
2, 5, and 6 were grown using a-type crucibles, and ingots 1, 3, and 4 were grown using b-type crucibles. Only ingot 5 was an n-type ingot. The ingots grown using a-type crucibles were single bulk crystals without any particles. The typical minority carrier lifetime of a wafer cut from the n-type ingot was $54.2 \mu \mathrm{s}$. The ingots grown using b-type crucibles were multicrystals containing $\mathrm{Si}_{\mathrm{x}} \mathrm{N}_{\mathrm{y}}$ particles. As shown in Fig. 4 (a), the oxygen concentration in the ingots grown using crucibles without a $\mathrm{Si}_{3} \mathrm{~N}_{4}$ coating was significantly higher than that in the ingots grown using crucibles with a $\mathrm{Si}_{3} \mathrm{~N}_{4}$ coating. The $\mathrm{Si}_{3} \mathrm{~N}_{4}$ coating was effective for preventing a reaction between the silica crucible and the Si melt. The segregation coefficient of oxygen is $\mathrm{k}_{0} 1$. The oxygen concentration at the center of the ingots is higher than that at the periphery because of the convex shape of the growing interface. As shown in Fig. 4 (b), the nitrogen concentration of the ingots grown using crucibles with a $\mathrm{Si}_{3} \mathrm{~N}_{4}$ coating was significantly higher than that of ingots grown using crucibles without a $\mathrm{Si}_{3} \mathrm{~N}_{4}$ coating. Nitrogen clearly dissolved from the $\mathrm{Si}_{3} \mathrm{~N}_{4}$ coating material into the $\mathrm{Si}$ melt, where it was saturated and incorporated in the ingots as inclusions during crystal growth.

Fig. 5 (a) shows a p-type ingot with a diameter of $10.3 \mathrm{~cm}$ grown using a crucible coated with a mixture of $\alpha$ - and $\beta-\mathrm{Si}_{3} \mathrm{~N}_{4}$ particles. The temperature reduction used for the growth was $5{ }^{\circ} \mathrm{C}$. As in case $\mathrm{I}$, a large number of $\mathrm{Si}_{\mathrm{x}} \mathrm{N}_{\mathrm{y}}$ particles appeared at the top surface of the ingot. To carry out the SEM and EBSD measurements, a small block was sampled from an area on the top surface of the ingot, as indicated by the red arrow in Fig. 5 (a). Figs. 5 (b) and (c) show the $\mathrm{Si}_{\mathrm{x}} \mathrm{N}_{\mathrm{y}}$ particles with a columnar structure observed by SEM at 400x and 2500x magnifications, respectively. To determine whether the $\mathrm{Si}_{\mathrm{x}} \mathrm{N}_{\mathrm{y}}$ particles were $\alpha-\mathrm{Si}_{3} \mathrm{~N}_{4}$ or $\beta-\mathrm{Si}_{3} \mathrm{~N}_{4}$, the structure was analyzed by EBSD. Figs. 5 (d), (e), and (f) show orientation image maps analyzed on the basis of EBSD patterns for $\mathrm{Si}, \alpha-\mathrm{Si}_{3} \mathrm{~N}_{4}$, and $\beta-\mathrm{Si}_{3} \mathrm{~N}_{4}$ taken from a cross section of the sample, respectively. The $\mathrm{Si}$ sample contained many $\mathrm{Si}_{\mathrm{x}} \mathrm{N}_{\mathrm{y}}$ particles, as shown in Fig. 5 (b), which correspond to the black dots in Fig. 5 (d). It was clear that although most of the $\mathrm{Si}_{\mathrm{x}} \mathrm{N}_{\mathrm{y}}$ particles did not act as nucleation sites, some of them acted as nucleation sites from which grains and grain boundaries appeared. However, it could not be distinguished which $\mathrm{Si}_{\mathrm{x}} \mathrm{N}_{\mathrm{y}}$ particles acted as nucleation sites. Very few signals from $\alpha-\mathrm{Si}_{3} \mathrm{~N}_{4}$ were detected, as shown in Fig. 5 (e), while a strong signal from $\beta$ $-\mathrm{Si}_{3} \mathrm{~N}_{4}$ was detected, as indicated in Fig. 5 (f). It was therefore clarified that there were very few $\alpha-\mathrm{Si}_{3} \mathrm{~N}_{4}$ particles in the sample and that most of the $\mathrm{Si}_{\mathrm{x}} \mathrm{N}_{\mathrm{y}}$ particles on the surface of the ingot shown in Figs. 5 (b) and (c) were $\beta-\mathrm{Si}_{3} \mathrm{~N}_{4}$. Therefore, the $\mathrm{Si}_{\mathrm{x}} \mathrm{N}_{\mathrm{y}}$ particles shown in Fig. 2 were determined to be $\beta-\mathrm{Si}_{3} \mathrm{~N}_{4}$. It was also confirmed by $\mathrm{XRD}$ that a large number of the $\mathrm{Si}_{\mathrm{x}} \mathrm{N}_{\mathrm{y}}$ particles on the top surface of the same ingot as 
shown in Fig. 5 (a) were $\beta-\mathrm{Si}_{3} \mathrm{~N}_{4}$. A large number of $\mathrm{Si}_{\mathrm{x}} \mathrm{N}_{\mathrm{y}}$ particles on the top surface of the ingot shown in Fig. 1 were also found to be $\beta-\mathrm{Si}_{3} \mathrm{~N}_{4}$ using the same EBSD method. A large number of $\mathrm{Si}_{3} \mathrm{~N}_{4}$ particles appearing on the top of the ingots in case I should be in both cases I and II. Therefore, in case II, the $\mathrm{Si}_{\mathrm{x}} \mathrm{N}_{\mathrm{y}}$ particles appearing on the top surface of the ingot, as shown in Fig. 3, were also determined to be $\beta-\mathrm{Si}_{3} \mathrm{~N}_{4}$.

\subsection{Effect of floating $\mathrm{Si}_{3} \mathrm{~N}_{4}$ particles on quality of multicrystalline $\mathrm{Si}$}

Some of the $\mathrm{Si}_{3} \mathrm{~N}_{4}$ particles attached on the surface of a growing ingot acted as nucleation sites, forming grains and grain boundaries. Figs. 6 (a) and (b) respectively show a p-type ingot grown using a crucible with a diameter of $33 \mathrm{~cm}$ and its cross section cut $4.8 \mathrm{~cm}$ below its top surface. The ingot was grown using a crucible coated with a mixture of $\alpha$ - and $\beta-\mathrm{Si}_{3} \mathrm{~N}_{4}$ particles. The temperature reduction used for the growth was $6.2{ }^{\circ} \mathrm{C}$. The ingot was $3420 \mathrm{~g}$ in mass, $21.5 \mathrm{~cm}$ in diameter, and $9 \mathrm{~cm}$ in height. Before the growth of the ingot, a large number of $\mathrm{Si}_{3} \mathrm{~N}_{4}$ particles were removed from the $\mathrm{Si}_{3} \mathrm{~N}_{4}$ coating material and floated on the surface of the $\mathrm{Si}$ melt. Three islands of $\mathrm{Si}_{3} \mathrm{~N}_{4}$ particles, shown by the red circles in Fig. 6, were attached to the top surface of the ingot. The ingot had small grains immediately below the islands, as shown in Fig. 6 (a). Fig. 6 (c) shows the distribution of the minority carrier lifetime in an as-cut cross section. The minority carrier lifetime below the islands was as high as that in the other cross-sectional area. The average minority carrier lifetime in the entire cross section was $6 \mu$ s for the as-cut surface and $25 \mu$ s for the passivated surface of the wafer. Fig. 6 (d) shows the etch-pit distribution of dislocations in the same cross section. The dislocation densities in the areas below the islands were the same or lower than those in the other cross-sectional area. According to these results, the $\mathrm{Si}_{3} \mathrm{~N}_{4}$ particles attached to the surface of the ingot did not seriously affect the quality of the ingot even though the grains in these areas were smaller than those in the other crosssectional area.

\section{Discussion}

The following transformation and precipitation processes can be considered to occur from our analysis of $\mathrm{Si}_{3} \mathrm{~N}_{4}$ particles on the surface of the ingots. Fig. 7 shows a schematic illustration summarizing the behavior of $\mathrm{Si}_{3} \mathrm{~N}_{4}$ particles coated on a crucible wall during cooling and crystal growth. Silica crucibles coated with a mixture of $\alpha$ and $\beta-\mathrm{Si}_{3} \mathrm{~N}_{4}$ particles were used. In case I, a large number of $\mathrm{Si}_{3} \mathrm{~N}_{4}$ particles were removed from the $\mathrm{Si}_{3} \mathrm{~N}_{4}$ coating material and initially floated on the surface of the $\mathrm{Si}$ 
melt as a mixture of $\alpha$ - and $\beta-\mathrm{Si}_{3} \mathrm{~N}_{4}$ particles. They then transformed into $\beta$ $\mathrm{Si}_{3} \mathrm{~N}_{4}$ particles through a reaction with the $\mathrm{Si}$ melt. Some of the floating $\mathrm{Si}_{3} \mathrm{~N}_{4}$ particles dissolved in the $\mathrm{Si}$ melt as nitrogen, and $\beta-\mathrm{Si}_{3} \mathrm{~N}_{4}$ particles then precipitated from the Si melt oversaturated by nitrogen during the cooling of the Si melt. It is possible that a few of the $\alpha-\mathrm{Si}_{3} \mathrm{~N}_{4}$ particles removed from the $\mathrm{Si}_{3} \mathrm{~N}_{4}$ coating material continued to float and remained as $\alpha-\mathrm{Si}_{3} \mathrm{~N}_{4}$ particles on the surface of the Si melt without undergoing a transformation or dissolution. In case II, nitrogen dissolved in the $\mathrm{Si}$ melt from the surface of the $\mathrm{Si}_{3} \mathrm{~N}_{4}$ coating material and became saturated in the $\mathrm{Si}$ melt at a higher temperature than the melting point of $\mathrm{Si}$. The $\beta-\mathrm{Si}_{3} \mathrm{~N}_{4}$ particles from the nitrogen-oversaturated Si melt then precipitated on the Si melt while it was cooled from above $1450{ }^{\circ} \mathrm{C}$ to the melting point of the $\mathrm{Si}$. The number of precipitated $\mathrm{Si}_{3} \mathrm{~N}_{4}$ particles is limited by the saturated concentration of nitrogen in the Si melt and depends on the temperature reduction. Such $\beta-\mathrm{Si}_{3} \mathrm{~N}_{4}$ particles floated near the center of the surface of the Si melt before crystal growth because of the low-temperature region of the melt. Finally, in both cases I and II, floating $\beta-\mathrm{Si}_{3} \mathrm{~N}_{4}$ particles appeared on the surface of the ingot, and had several morphologies depending on the growth conditions. The $\mathrm{Si}_{3} \mathrm{~N}_{4}$ particles in case II were deemed to be $\beta-\mathrm{Si}_{3} \mathrm{~N}_{4}$ because only $\beta-\mathrm{Si}_{3} \mathrm{~N}_{4}$ was detected from the $\mathrm{Si}_{3} \mathrm{~N}_{4}$ particles appearing on the top surface of the ingots in case $\mathrm{I}$. The $\mathrm{Si}_{3} \mathrm{~N}_{4}$ particles appearing in case I should be a mixture of both cases I and II. The $\beta-\mathrm{Si}_{3} \mathrm{~N}_{4}$ particles became attached to the surface of a growing seed crystal or ingot, and some of them acted as nucleation sites, forming grains and grain boundaries. Nitrogen in the $\mathrm{Si}$ melt was also incorporated in the ingots as $\beta-\mathrm{Si}_{3} \mathrm{~N}_{4}$ inclusions during crystal growth [19]. Buonassisi et al. reported that $\mathrm{Si}_{3} \mathrm{~N}_{4}$ particles can be a significant source of contaminants, such as metal point defects, in Si ingots [28]. The $\mathrm{Si}_{3} \mathrm{~N}_{4}$ formation process is the same in $\mathrm{Si}$ crystal growth using crucibles with a $\mathrm{Si}_{3} \mathrm{~N}_{4}$ coating such as directional solidification growth. No difference was found in the $\mathrm{Si}_{3} \mathrm{~N}_{4}$ formation process for the $\mathrm{p}$ - and $\mathrm{n}$-type ingots.

Reimann et al. and Trempa et al. reported that the nitrogen concentration at the center of ingots was lower than that at the periphery for the casting growth of multicrystalline $\mathrm{Si}$ and that the nitrogen concentration depended on the growth rate [7, 8]. On the other hand, the nitrogen concentration at the center of the ingots is higher than that at the periphery as shown in Fig. 4. Nitrogen dissolved in the Si melt continuously evaporated from the surface of the melt. Therefore, the nitrogen concentration was lowest near the melt surface and increased toward the bottom of the melt when the convection was suppressed. In the present method, the Si melt had a large low-temperature region in its upper central part, thus the convection should have 
been somewhat suppressed. The growing interface had a convex shape in the growth direction. Therefore, the center of the ingot grew in a deeper part of the melt, which had a higher nitrogen concentration than the periphery of the ingot. As the segregation coefficient of nitrogen is $\mathrm{k}_{0}=0.0007$ [29], the nitrogen concentration in the melt increased near the center of the ingot, and it also increased at the center of the ingot. Moreover, it became more difficult for nitrogen to diffuse and evaporate in the melt near the center of the ingot than near the periphery as the ingot became larger. Therefore, the nitrogen concentration in the melt rapidly increased near the center of the ingot. This is the reason why the nitrogen concentration at the center of the ingot was higher than that at the periphery. The same distribution was observed for the oxygen concentration for the similar reason.

\section{Conclusions}

A noncontact crucible method was used to investigate the process by which a $\mathrm{Si}_{3} \mathrm{~N}_{4}$ coating material forms $\mathrm{Si}_{3} \mathrm{~N}_{4}$ particles on the surface of Si melts and ingots in two different cases, cases I and II. The ingots were grown using crucibles with and without a mixture of $\alpha$ - and $\beta-\mathrm{Si}_{3} \mathrm{~N}_{4}$ particles. Before the growth of the ingots, $\mathrm{Si}_{3} \mathrm{~N}_{4}$ particles originating from the $\mathrm{Si}_{3} \mathrm{~N}_{4}$ coating material floated on the surface of the Si melt. These $\mathrm{Si}_{3} \mathrm{~N}_{4}$ particles became attached to the surface of a seed crystal or ingot, and some of them acted as nucleation sites forming grains and grain boundaries. The $\mathrm{Si}_{3} \mathrm{~N}_{4}$ particles on the surface of the ingots had several morphologies, including needle-like, columnar, leaf-like, and hexagonal structures, and occasionally contained SiC particles. The nitrogen concentration in the ingots grown using crucibles with a $\mathrm{Si}_{3} \mathrm{~N}_{4}$ coating was significantly higher than that in ingots grown using crucibles without such a coating. Nitrogen dissolved from the $\mathrm{Si}_{3} \mathrm{~N}_{4}$ coating material into the Si melt, became saturated in the Si melt and was incorporated into the growing ingot while the Si melt cooled. From the orientation image maps analyzed through an EBSD pattern of $\mathrm{Si}_{3} \mathrm{~N}_{4}$ particles on the surface of the ingots in case I, it was clarified that most of the $\mathrm{Si}_{3} \mathrm{~N}_{4}$ particles were $\beta-\mathrm{Si}_{3} \mathrm{~N}_{4}$. It was also confirmed by XRD that the $\mathrm{Si}_{3} \mathrm{~N}_{4}$ particles on the top surface of the same ingot were $\beta-\mathrm{Si}_{3} \mathrm{~N}_{4}$. In both cases I and II, it was considered that the removed or dissolved $\mathrm{Si}_{3} \mathrm{~N}_{4}$ coating materials, which consisted of a mixture of $\alpha$ and $\beta-\mathrm{Si}_{3} \mathrm{~N}_{4}$ particles, finally changed into $\beta-\mathrm{Si}_{3} \mathrm{~N}_{4}$ in the form of transformers or precipitates on the surface of the Si melt. $\mathrm{Si}_{3} \mathrm{~N}_{4}$ particles attached on the surface of the seed crystals or ingots did not seriously affect the ingot quality even though the grains in the area were smaller than those in other cross-sectional areas. 


\section{Acknowledgements}

This study was supported by Japan Science and Technology Agency (JST) under the

Ministry of Education, Culture, Sports, Science and Technology of Japan (MEXT) and the New Energy and Industrial Technology Development Organization (NEDO) under the Ministry of Economy, Trade and Industry (METI). We would like to thank S. Ochi of Kyoto University for his support. 


\section{References}

[1] H. Sugimoto, M. Tajima, T. Eguchi, I. Yamaga, T. Saitoh, Materials Science in Semiconductor Processing 9 (2006) 102.

[2] T. F. Li, H. C. Huang, H. W. Tsai, A. Lan, C. Chuck, C. W. Lan, Journal of Crystal Growth 340 (2012) 202.

[3] F.-M. Kiessling, F. Büllesfeld, N. Dropka, Ch. Frank-Rotsch, M. Müller, P. Rudolph, Journal of Crystal Growth 360 (2012) 81.

[4] K. Nakajima, R. Murai, K. Morishita, K. Kutsukake, N. Usami, Journal of Crystal Growth 344 (2012) 6.

[5] K. Nakajima, K. Morishita, R. Murai, K. Kutsukake, Journal of Crystal Growth 355 (2012) 38 .

[6] K. Nakajima, R. Murai, K. Morishita, K. Kutsukake, Journal of Crystal Growth 372 (2013) 121.

[7] C. Reimann, M. Trempa, J. Friedrich, G. Müller, Journal of Crystal Growth 312 (2010) 1510.

[8] M. Trempa, C. Reimann, J. Friedrich, G. Müller, Journal of Crystal Growth 312 (2010) 1517.

[9] J. Li, R. R. Prakash, K. Jiptner, J. Chen, Y. Miyamura, H. Harada, K. Kakimoto, A. Ogura, T. Sekiguchi, Journal of Crystal Growth 377 (2013) 37.

[10] W. Kaiser, C. D. Thurmond, Journal of Applied Physics 30 (1959) 427.

[11] H. M. Jennings, Journal of Materials Science 18 (1983) 951.

[12] E. T. Turkdogan, P. M. Bills, V. A. Tippett, Journal of Applied Chemistry 8 (1958) 296.

[13] F. L. Riley, Journal of American Ceramics Society 83 (2000) 245.

[14] C-M. Wang, X. Pan, M. Rühle, F. L. Riley, M. Mitomo, Journal of Materials Science 31 (1996) 5281.

[15] H. Fujimori, N. Sato, K. Ioku, S. Goto, T. Yamada, Journal of American Ceramics Society 83 (2000) 2251.

[16] D. R. Messier, F. L. Riley, R. J. Brook, Journal of Materials Science 13 (1978) 1199.

[17] C. Creskovich, S. Prochazka, Journal of American Ceramics Socity 60 (1977) 471.

[18] H. Suematsu, M. Mitomo, T. E. Mitchell, J. J. Petrovic, O. Fukunaga, N. Ohashi, Journal of American Ceramics Society 0 (1997) 615.

[19] A. K. Søiland, E. J. ł vrelid, T. A. Engh, O. Lohne, J. K. Tuset, \1Gjerstad, Materials Science in Semiconductor Processing 7 (2004) 39.

[20] L. Alphei, A. Braun, V. Becker, A. Feldhoff, J. A. Becker, E. Wulf, C. Krause, Fr.-W. Bach, Journal of Crystal Growth 311 (2013) 1250. 
[21] B. Drevet, O. Pajani, N. Eustathopoulos, Solar Energy Materials \& Solar Cells 94 (2010) 425.

[22] I. Brynjulfsen, A. Bakken, M. Tangstad, L. Arnberg, Journal of Crystal Growth 312 (2010) 2404.

[23] T. Tachibana, T. Sameshima, T. Kojima, K. Arafune, K. Kakimoto, Y. Miyamura, H. Harada, T. Sekiguchi, Y. Ohshita, A. Ogura, Journal of Applied Physics 111 (2012) 074505.

[24] T. Tachibana, T. Sameshima, T. Kojima, K. Arafune, K. Kakimoto, Y. Miyamura, H. Harada, T. Sekiguchi, Y. Ohshita, A. Ogura, Japanese Journal of Applied Physics 51 (2012) 02BP08.

[25] W. C. Dash, Journal of Applied Physics 30 (1959) 459.

[26] J. Czochralski, Zeitschrift Physikalische Chemie 92 (1917) 219.

[27] H. Takato, I. Sakata, R. Shimokawa, Japanese Journal of Applied Physics Letters Part 2, Letters 40 (2001) L1003.

[28] T. Buonassisi, A. A. Istratov, M. D. Pickett, J.-P. Rakotoniaina, O. Breitenstein, M. A. Marcus, S. M. Heald, E. R. Weber, Journal of Crystal Growth 287 (2006) 402.

[29] Y. Yatsurugi, N. Akiyama, Y. Endo, Journal of Electrochemical Society 120 (1973) 975. 


\section{Figure captions}

Fig. 1 (a) p-Type ingot with a diameter of $23 \mathrm{~cm}$ grown using a crucible coated with a mixture of $\alpha$ - and $\beta-\mathrm{Si}_{3} \mathrm{~N}_{4}$ particles. (b) Small particles on the top surface of the ingot. (c) EDX spectrum of the same small particles, which indicates the existence of Si and $\mathrm{N}$ elements along with $\mathrm{C}$ elements. (d) Distribution of the minority carrier lifetime in an as-cut cross section cut $0.9 \mathrm{~cm}$ below the top surface.

Fig. 2 Distribution of Si, C, N, and O elements based on a combined image obtained by EDX analysis of small particles shown by the yellow arrow on the top surface of the same ingot. The $\mathrm{Si}_{\mathrm{x}} \mathrm{N}_{\mathrm{y}}$ particles had several different morphologies, including needle-like, columnar, and leaf-like structures, and contained SiC particles.

Fig. 3 (a) p-Type ingot with a diameter of $23 \mathrm{~cm}$ grown using a crucible coated with a mixture of $\alpha$-and $\beta-\mathrm{Si}_{3} \mathrm{~N}_{4}$ particles. (b) Small particles on the top surface of the ingot. (c) $\mathrm{Si}_{\mathrm{x}} \mathrm{N}_{\mathrm{y}}$ particles on the top surface of the ingot observed through an SEM. (d) EDX spectrum of the small particles on the top surface of the ingot, in which $\mathrm{Si}$ and $\mathrm{N}$ elements were detected along with $\mathrm{C}$ elements.

Fig. 4 (a) Oxygen concentrations measured at the center and periphery areas of six ingots. The former and latter concentrations for an ingot correspond to its center (C) and periphery $(\mathrm{P})$ part, respectively. (b) Nitrogen concentrations measured at the center and periphery areas of the six ingots. The former and latter concentrations for an ingot correspond to its center $(\mathrm{C})$ and periphery $(\mathrm{P})$ areas, respectively. (c) Schematic diagram of a-type growth using a crucible without $\mathrm{Si}_{3} \mathrm{~N}_{4}$ coating. (d) Schematic diagram of b-type growth using a crucible with $\mathrm{Si}_{3} \mathrm{~N}_{4}$ coating. Ingots (2), (5), and (6) were grown using a-type crucibles, and ingots (1), (3), and (4) were grown using b-type crucibles.

Fig. 5 (a) p-Type ingot with a diameter of $10.3 \mathrm{~cm}$ grown using a crucible coated with a mixture of $\alpha$ - and $\beta-\mathrm{Si}_{3} \mathrm{~N}_{4}$ particles as in case I. (b) $\mathrm{Si}_{\mathrm{x}} \mathrm{N}_{\mathrm{y}}$ particles with a columnar structure observed by SEM at 400x magnification. (c) $\mathrm{Si}_{\mathrm{x}} \mathrm{N}_{\mathrm{y}}$ particles with a columnar structure observed by SEM at 2500x magnification. (d) Orientation image map analyzed on the basis of EBSD pattern for Si. The black dots correspond to $\mathrm{Si}_{\mathrm{x}} \mathrm{N}_{\mathrm{y}}$ particles in the Si ingot. (e) Orientation image map analyzed on the basis of EBSD pattern for $\alpha-\mathrm{Si}_{3} \mathrm{~N}_{4}$. Very few $\alpha$ $-\mathrm{Si}_{3} \mathrm{~N}_{4}$ particles were detected. (f) Orientation image map analyzed on the basis of EBSD pattern for $\beta-\mathrm{Si}_{3} \mathrm{~N}_{4} . \quad \beta-\mathrm{Si}_{3} \mathrm{~N}_{4}$ particles were clearly detected.

Fig. 6 (a) p-Type ingot grown using a crucible with a diameter of $33 \mathrm{~cm}$ coated with a 
mixture of $\alpha$ - and $\beta-\mathrm{Si}_{3} \mathrm{~N}_{4}$ particles. (b) Cross section cut $4.8 \mathrm{~cm}$ below the top surface. (c) Distribution of the minority carrier lifetime in the same as-cut cross section. (d) Etch-pit distribution of dislocations in the same cross section.

Fig. 7 Schematic illustration summarizing the behavior of $\mathrm{Si}_{3} \mathrm{~N}_{4}$ particles coated on a crucible wall during cooling and crystal growth. 
(a)

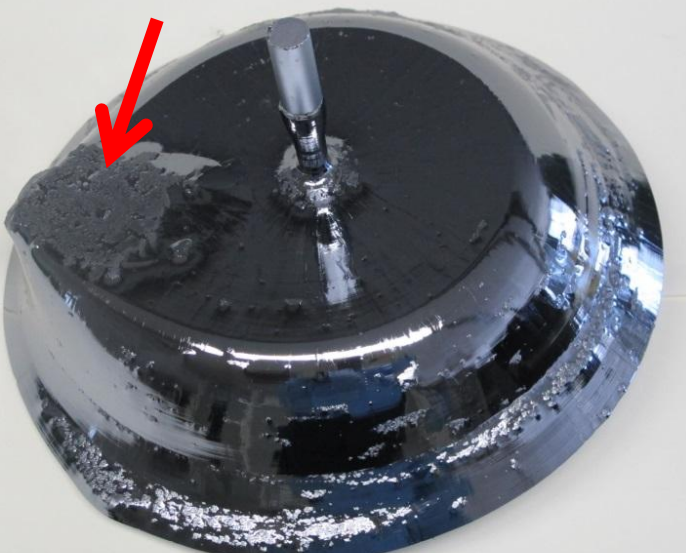

\section{Diameter: $23 \mathrm{~cm}$}

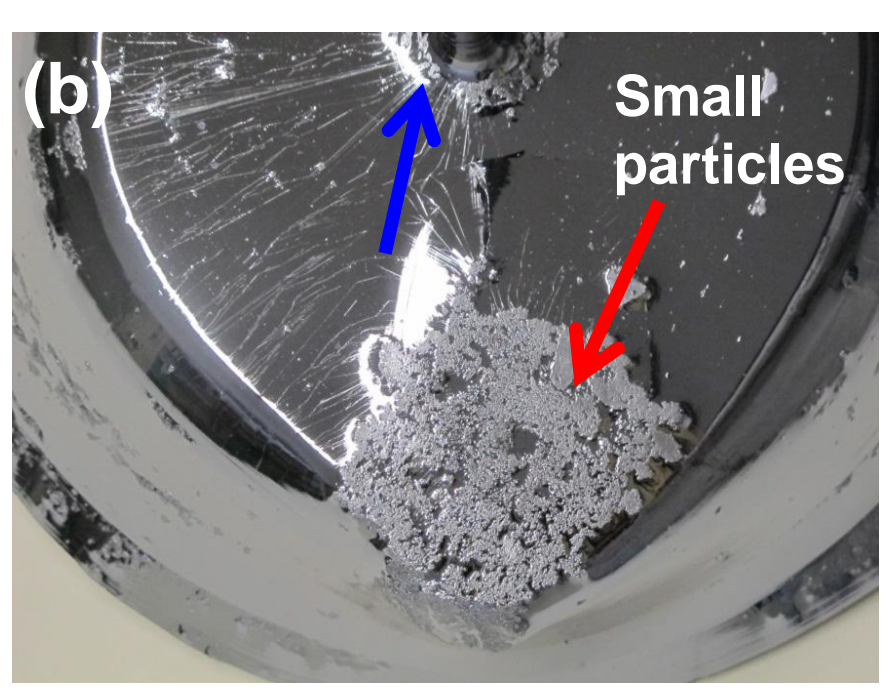

(c)
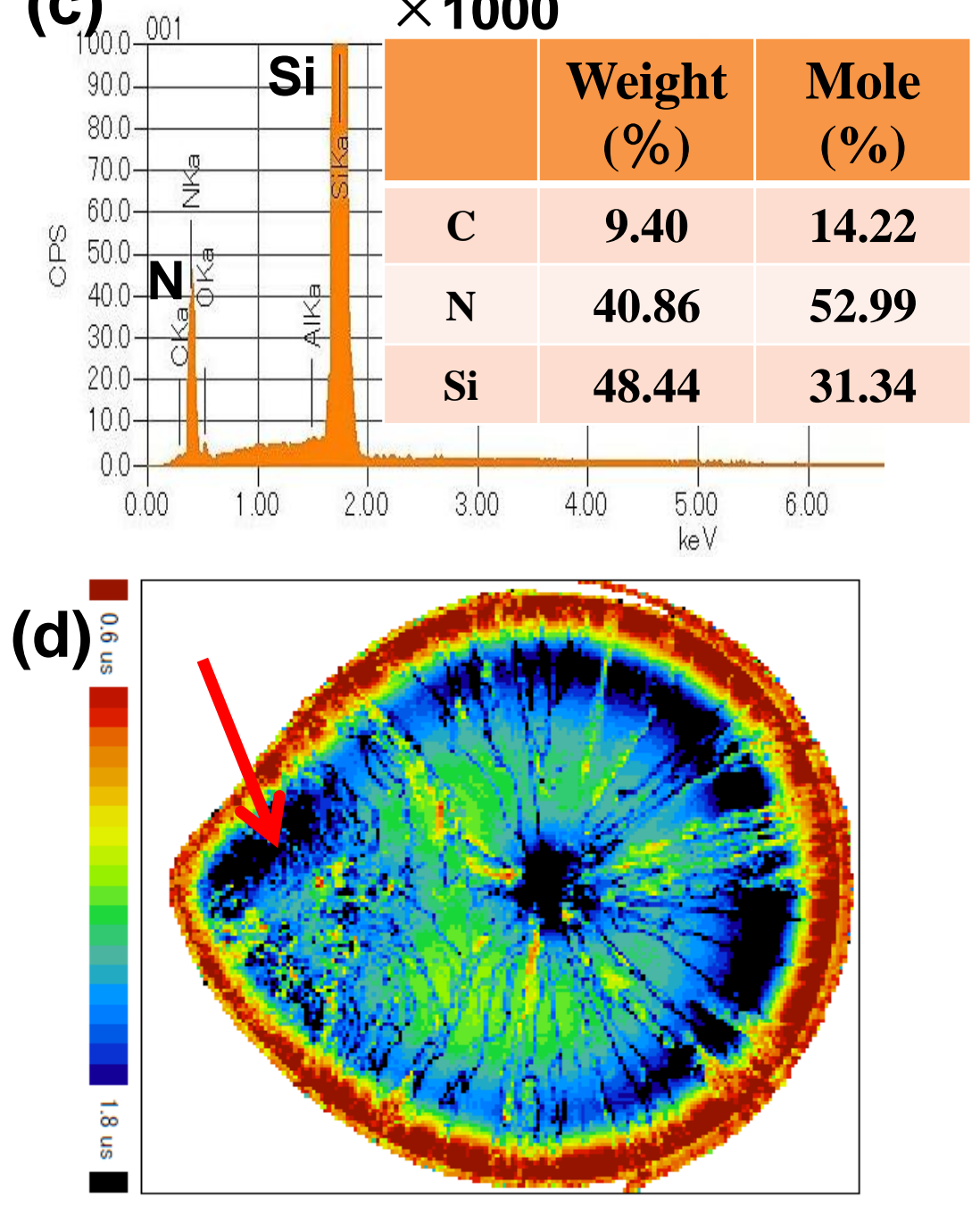

Fig. 1 K. Nakajima 


\section{Distribution of elements by a combination image}
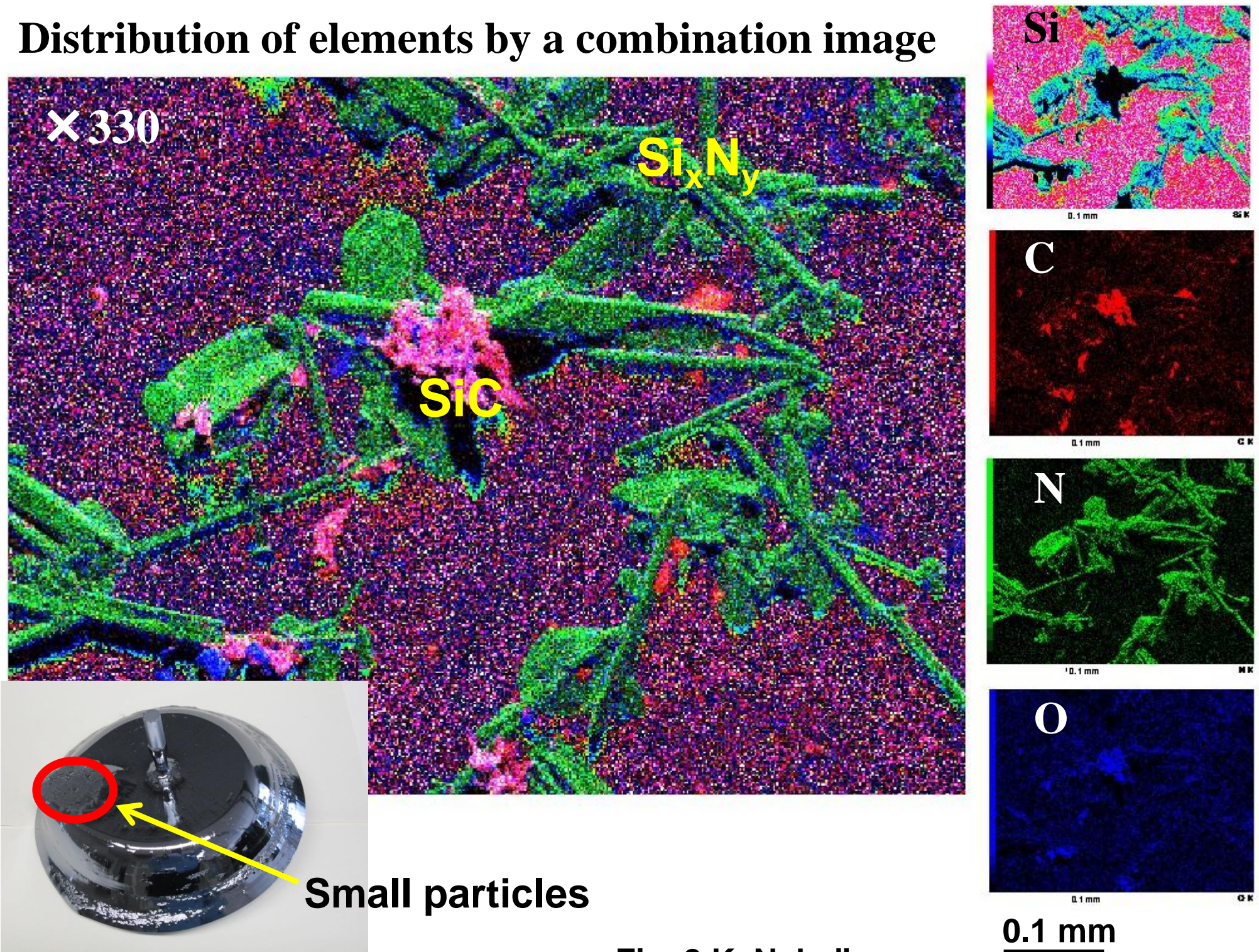

Fig. 2 K. Nakajima 

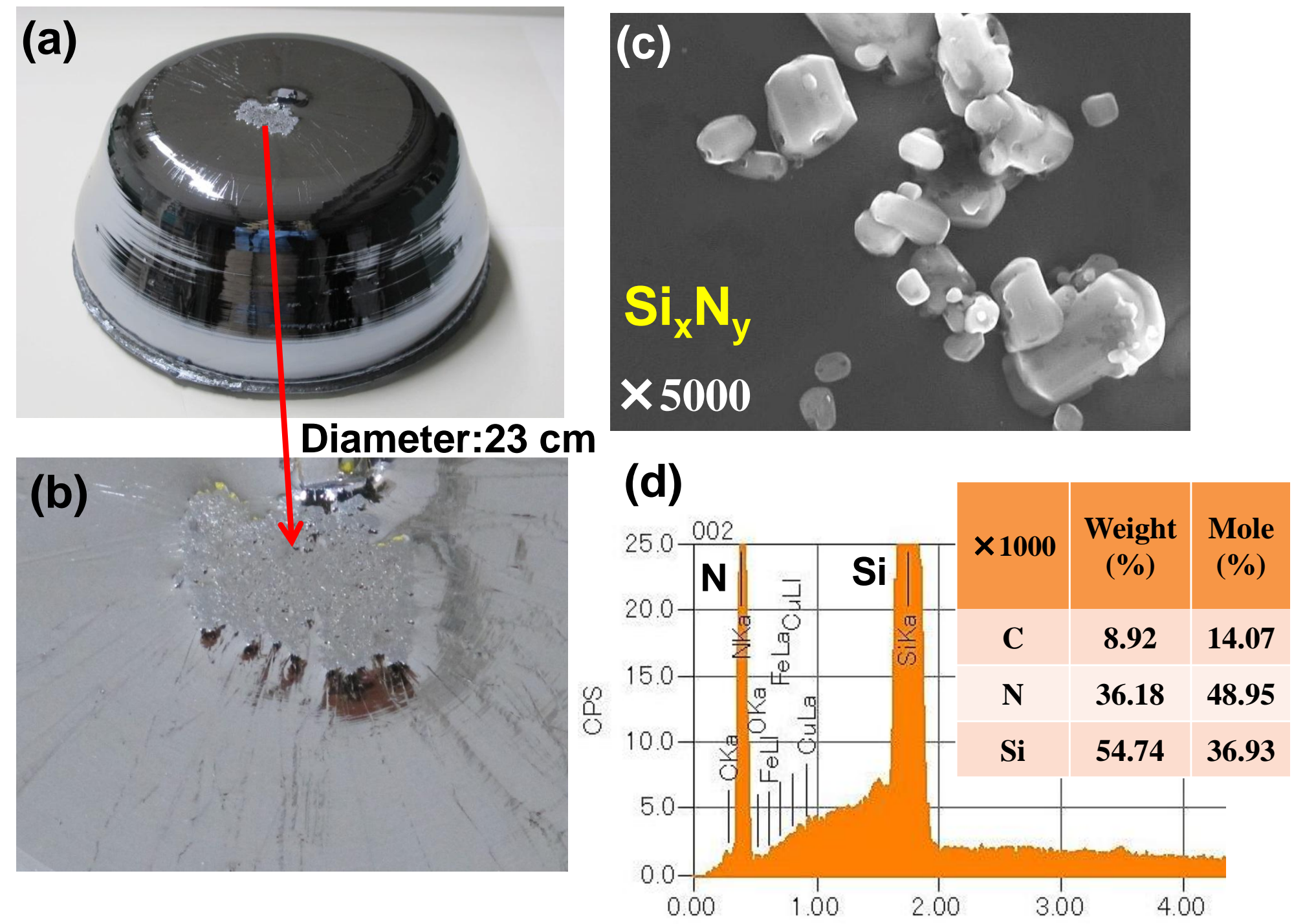

Fig. 3 K. Nakajima 
(a)

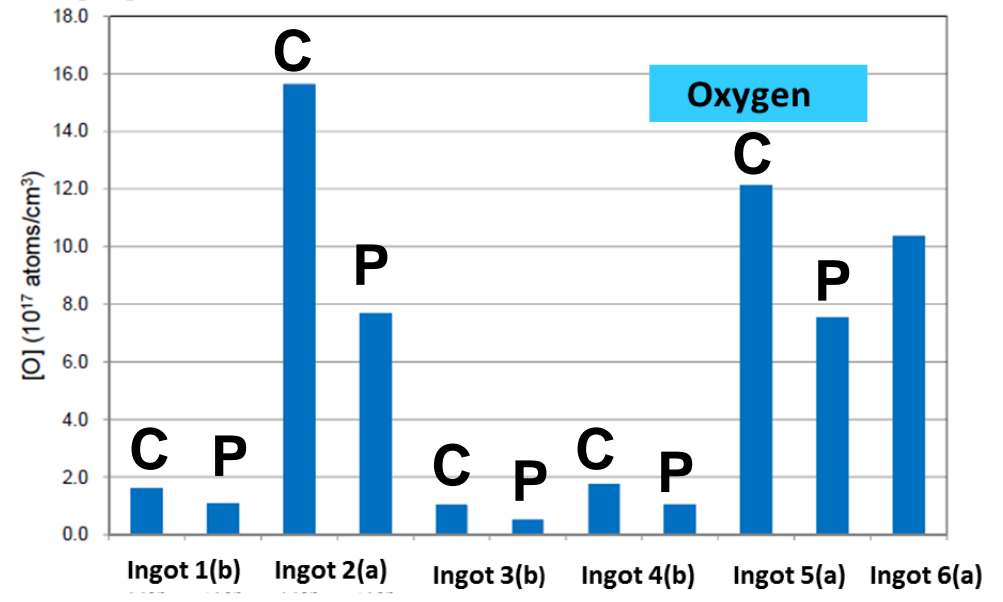

(c)

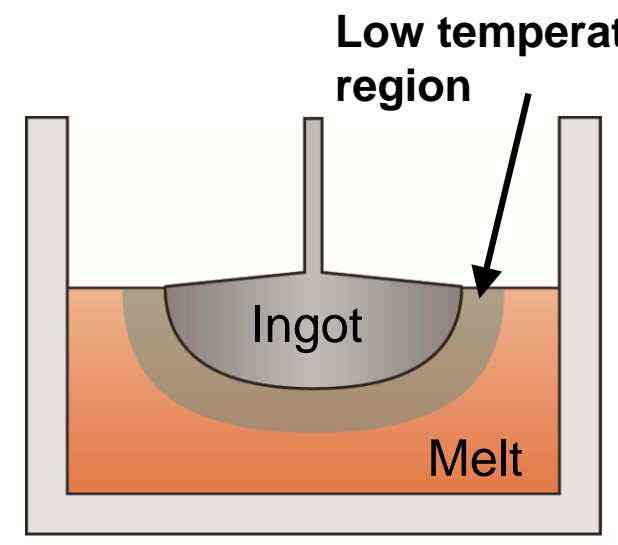

Crucible: $33 \mathrm{~cm} \phi$

Fig. 4 K. Nakajima a-Type (b)

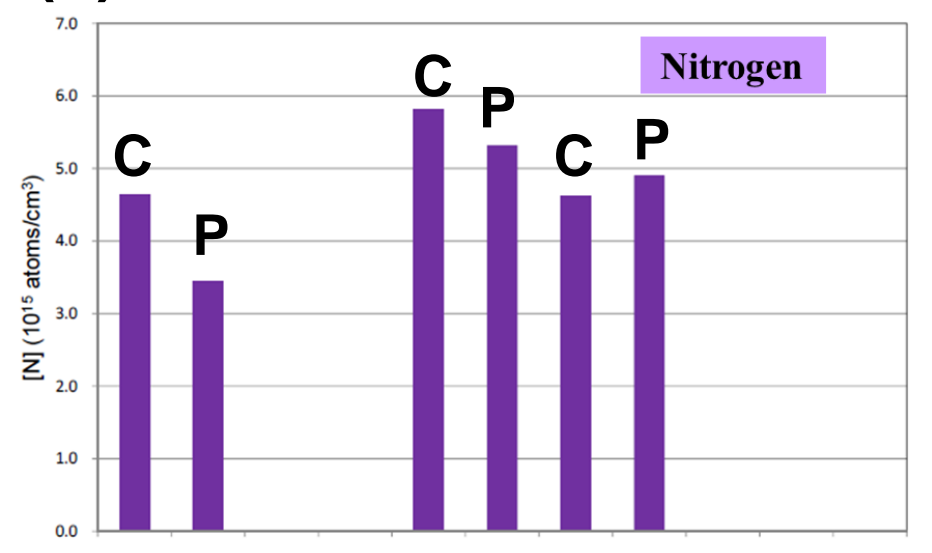

Ingot 1(b) Ingot 2(a) Ingot 3(b) Ingot 4(b) Ingot 5(a) Ingot 6(a)

(d) $\mathrm{Si}_{3} \mathrm{~N}_{4} \quad$ Low temperature

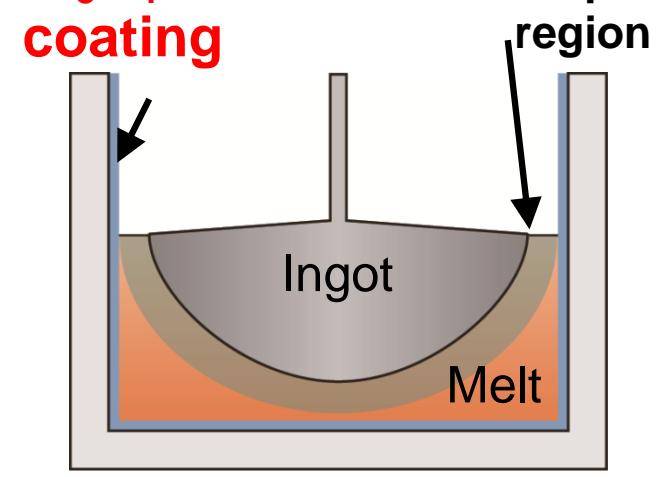

Crucible: $33 \mathrm{~cm} \phi$

b-Type 


\section{$\beta-\mathrm{Si}_{3} \mathrm{~N}_{4}$ particles}

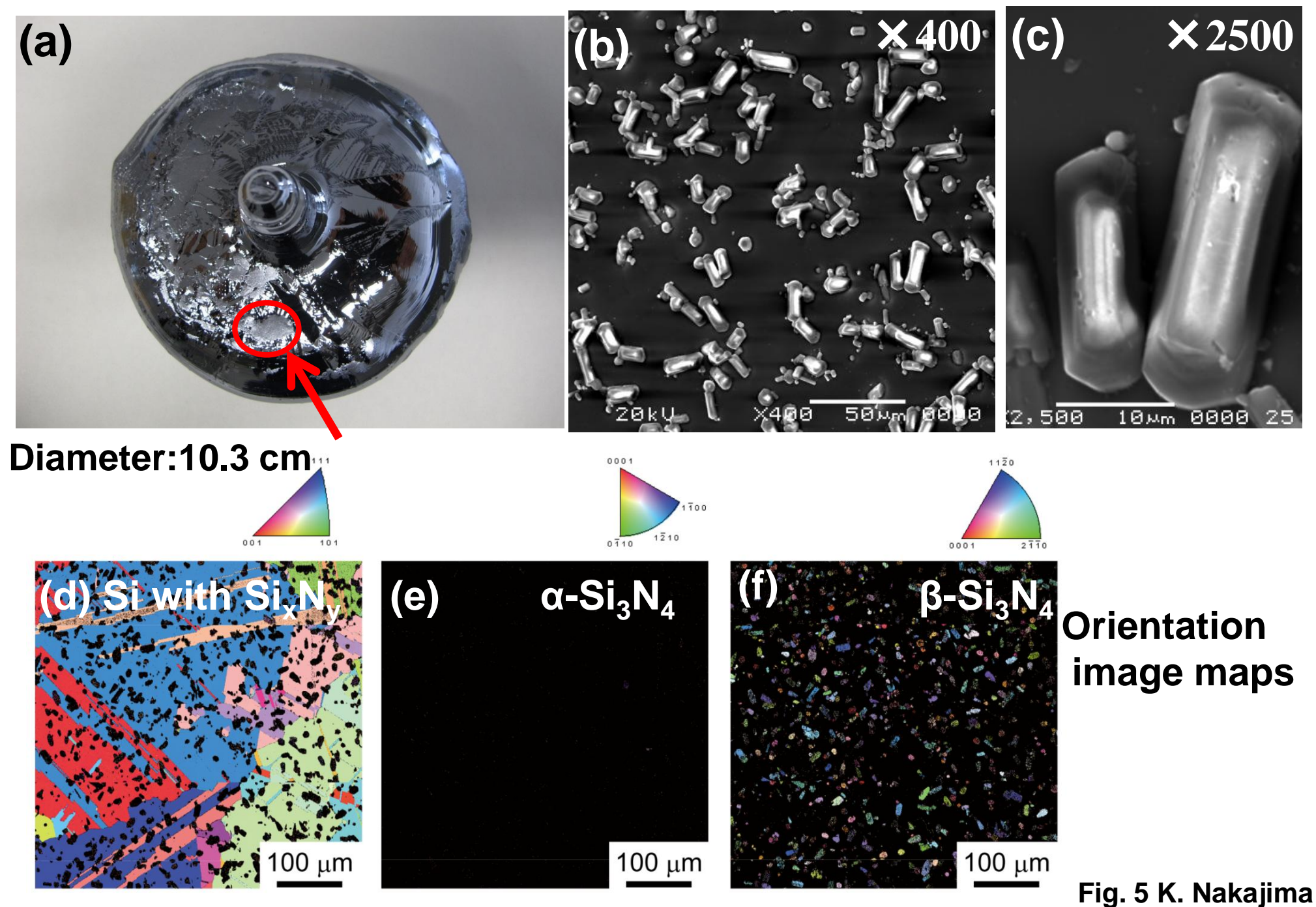

Fig. 5 K. Nakajima 

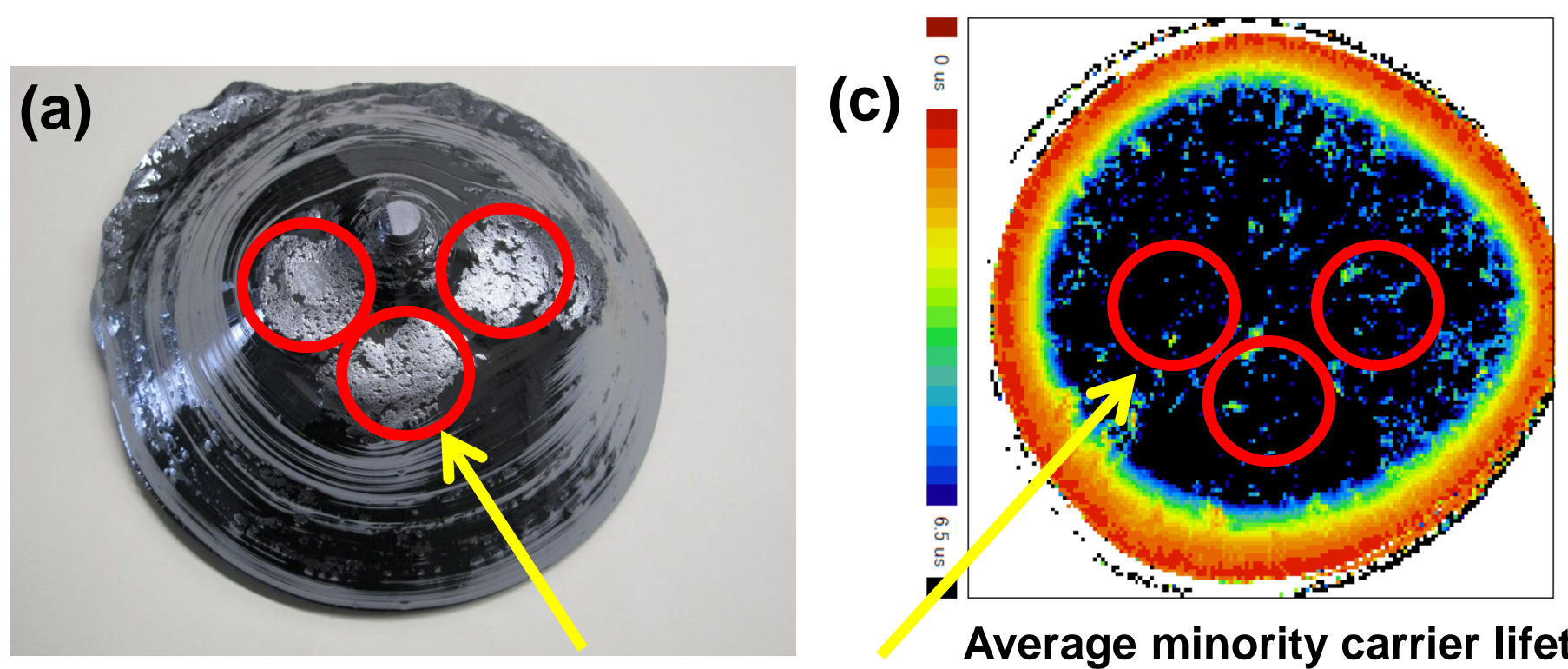

$\mathrm{Si}_{3} \mathrm{~N}_{4}$ particles for as-cut cross section: $6 \mu \mathrm{s}$

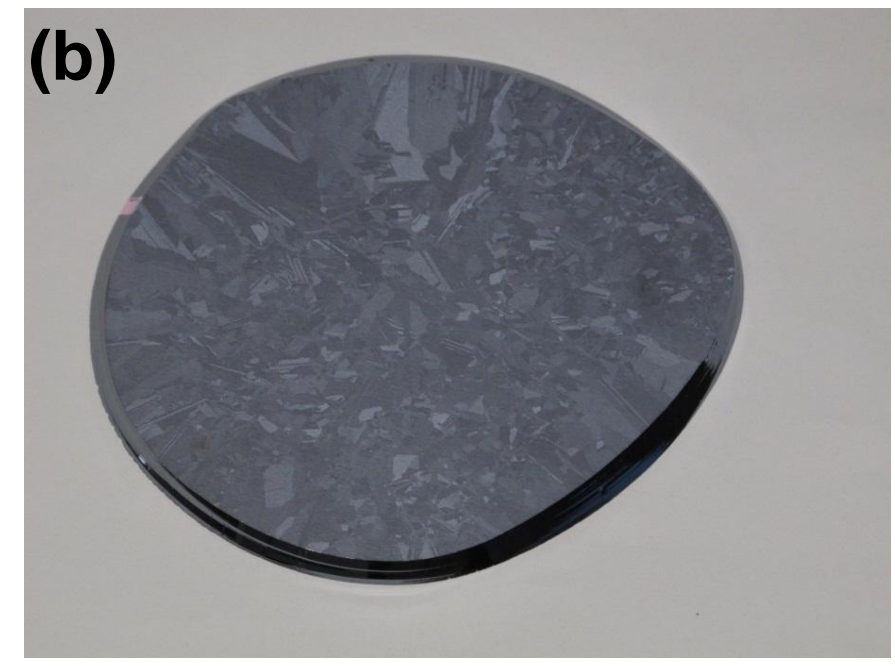

(d)

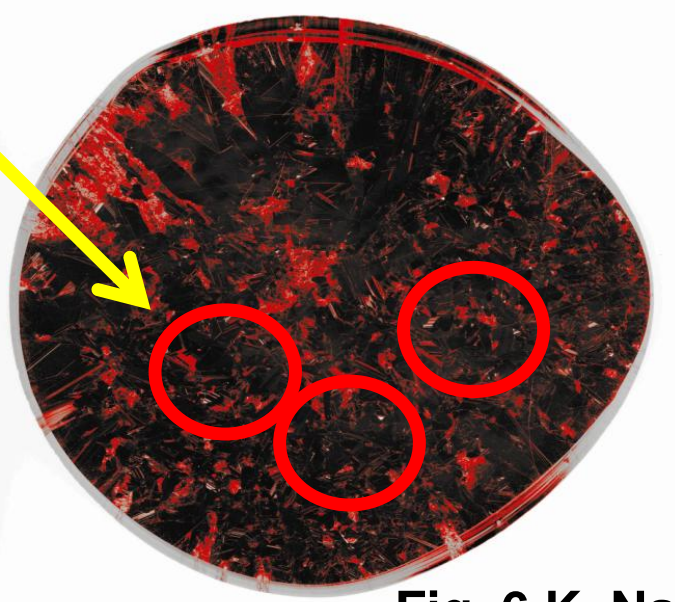

Fig. 6 K. Nakajima 


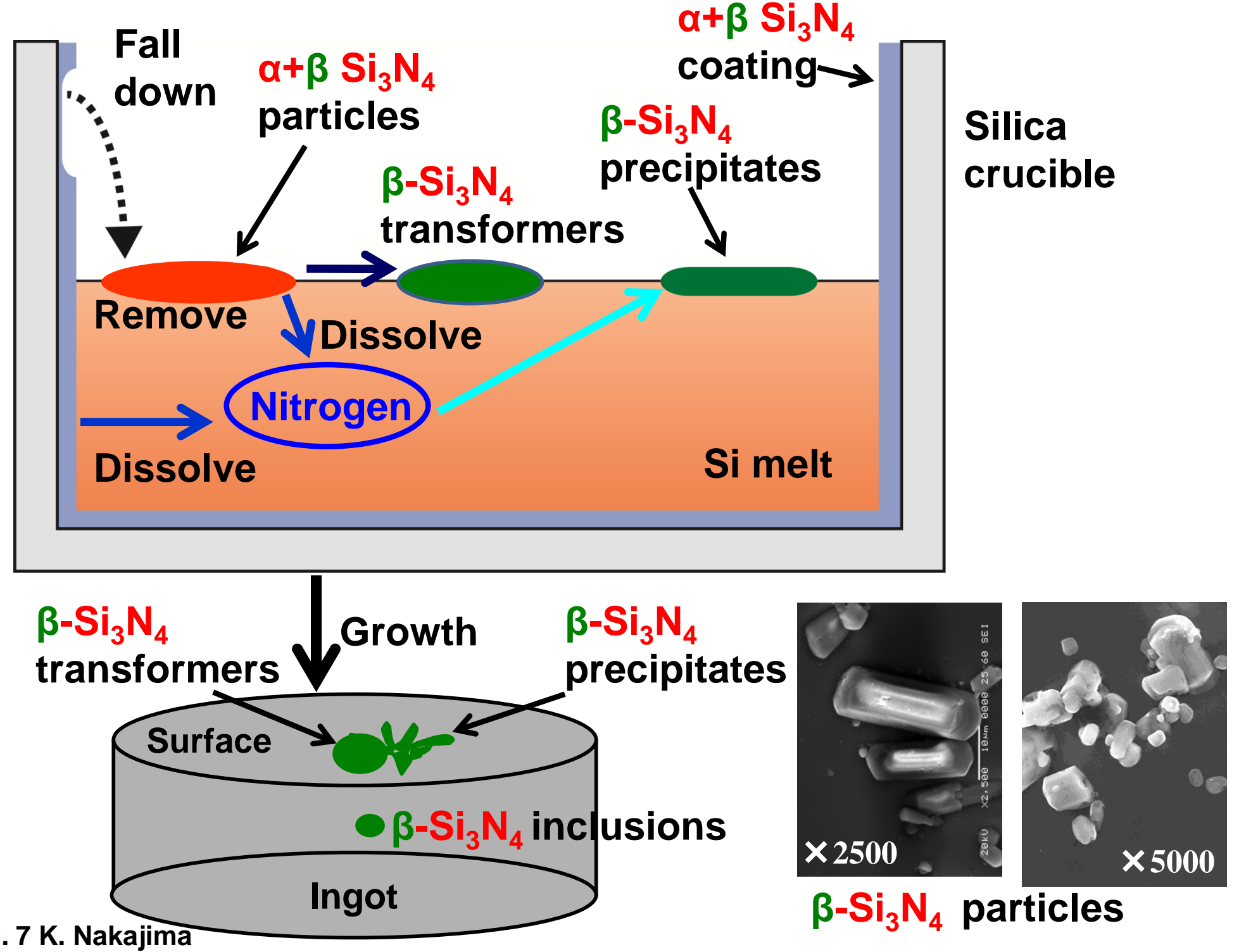

Fig. 7 K. Nakajima 